\title{
DESAIN SISTEM INFORMASI AKUNTANSI PERSEDIAAN OBAT BERBASIS KOMPUTER BERDASARKAN BATCH NUMBER DAN EXPIRED DATE
}

\author{
Mardiana Andarwati \\ Fakultas Teknologi Informasi Universitas Merdeka Malang \\ email: mardianaaan@gmail.com/NoTelepon 081553663275
}

\begin{abstract}
Abstrak
Without the use of accounting information systems on data collection of medical supplies through the process of buying or selling drugs based on the batch number and expired date is takes more time in the service of payment transactions, because (a) they have to be calculated manually or with a calculator, (b) take time to monitor the inventory stock existing drugs (inventory check) because it is done manually, (c) take time in making the report, because employees have to reopen the existing data, so the work becomes less effective, (d) the possibility of data-data that is lost because not or forgot to record. Inventory of information system design based on computer-based drug batch number and expiration date using Accurate v.4 data collection will further help facilitate drug supply. Among other design inventory, purchasing credits, purchase order, debt repayment, cash sales, and inventory report based drug batch number and expired date.
\end{abstract}

Keyword: Sistem informasi akuntansi, inventory, batch number, expired date

\section{PENDAHULUAN}

\section{Latar Belakang}

Hubungan antara sistem informasi akuntansi persediaan obat dengan batch number serta expired date diawali dari persediaan yang terbentuk karena adanya proses pembelian dan proses penjualan. Sistem informasi akuntansi persediaan dirancang untuk menangani transaksi yang bersangkutan dengan mutasi persediaan yang disimpan digudang. Dimana persediaan yang ada digudang perlu mengetahui batch number serta expired date (Kurniawan, Paulus Christianto. 2008)

Sistem informasi akuntansi persediaan tidak berdiri sendiri tetapi saling berkaitan dengan sistem pembelian dan sistem penjualan. Dan sistem ini sangat dibutuhkan karena dengan adanya sistem informasi akuntansi persediaan maka 
persediaan dapat ditingkatkan efifiensi dan efektifitasnya (Kurniawan, Paulus Christianto. 2008).

Sistem informasi akuntansi persediaan obat berdasarkan batch number dan expired date adalah aktifitas yang dilakukan bagian akuntansi yang berhubungan dengan persediaan obat yaitu mencatat transaksi pembelian dan penjualan atau transaksi lainnya yang berhubungan dengan barang yang membutuhkan batch number dan expired date (Lutfia P, 2009).

Menurut Lutfia P (2009) aktifitas penginputan batch number dan expired date dari barang-barang yang dibeli atau dijual dilakukan setelah bagian akuntansi selesai mencatat transaksi pembelian dan penjualan yang membutuhkan batch number dan expired date.

Pengelolaan informasi akuntansi persediaan obat biasanya dikerjakan secara manual. Tanpa penggunaan sistem informasi akuntansi persediaan yang berbasis komputer maka pendataan persediaan obat yang berdasarkan batch number dan expired date melalui transaksi jual beli obat hanya menggunakan buku catatan manual dan kalkulator untuk sistem pembukuannya.

Penggunaan alat bantu komputer sebagai pendukung dalam bidang akuntansi sudah merupakan kebutuhan mutlak. Perusahaan dagang membuat suatu laporan keuangan maupun penyesuaian laporan akhir periode dibuat secara manual. Akan tetapi setelah dikeluarkannya sebuah aplikasi akuntansi yaitu ACCURATE v.4 maka dalam pembuatan laporan persediaan obat yang didasarkan batch number dan expired date akhir periode menjadi lebih mudah dan cepat.

Apotek " $X$ " di Malang proses pencatatan transaksi persediaan obat yang dibeli dan terjual masih menggunakan sistem manual dengan menggunakan buku catatan dan kalkulator untuk sistem pembukuannya. Hal tersebut sangat berpengaruh pada perusahaan itu sendiri, baik untuk kelangsungan dan perkembangan usahanya. Maka tidak jarang masalah informasi yang kurang akurat sering terjadi pada apotik " $X$ " di Malang. Atas dasar tersebut maka penulis memberikan dan memperkenalkan software yang bisa lebih efektif dan efisien dalam mencatat semua obat yang dibeli dan terjual berdasarkan pencatatan batch number dan expired date yang terjadi pada apotik " $X$ " di Malang 


\section{Perumusan Masalah}

Permasalahan umum adalah bagaimanakah desain sistem informasi akuntansi persediaan obat berbasis komputer berdasarkan batch number dan expired date?

Permasalahan khusus adalah bagaimana desain sistem informasi persediaan obat berdasarkan batch number dan expired date; pembelian kredit obat berdasarkan batch number dan expired date; order pembelian berdasarkan batch number dan expired date; pelunasan hutang berdasarkan batch number dan expired date; penjualan tunai berdasarkan batch number dan expired date pada apotik " $X$ " di Malang; bagaimana laporan persediaan obat berdasarkan batch number dan expired date pada apotik " $X$ " di Malang?

\section{Tujuan Penelitian}

Dapat mendesain sistem informasi persediaan obat berdasarkan batch number dan expired date, pembelian kredit obat berdasarkan batch number dan expired date order pembelian berdasarkan batch number dan expired date pelunasan hutang berdasarkan batch number dan expired date penjualan tunai berdasarkan batch number dan expired date pada apotik " $X$ " di Malang; bagaimana laporan persediaan obat berdasarkan batch number dan expired date pada apotik?

\section{TINJAUAN PUSTAKA}

\section{Pengertian Desain sistem}

James A. Hall, 2004, a system is a group of two or more interrelated components or subsystems that serve a common purpose, kemudian menurut Romney\& Steinbart, 2006 hal 4, a system is a set of two or more interrelated components that interact to achieve a goal.

Mendesain sistem adalah sebuah proses menerjemahkan kebutuhan pemakai informasi ke dalam alternatif rancangan sistem informasi. Desain sistem dilakukan berdasarkan informasi yang didapatkan oleh analisis sistem (Mulyadi, 2001:51). Jogiyanto (2001:196) mendefinisikan desain sistem sebagai penggambaran, 
perencanaan, dan pembuatan sketsa atau pengaturan beberapa elemen yang terpisah ke dalam satu kesatuan yang utuh dan berfungsi

Menurut Purnomo (2002:33), perancangan sistem merupakan sebuah proses yang terdiri atas beberapa kegiatan, yaitu sebagai berikut.

1. Menentukan secara tepat dan terperinci kebutuhan dan bentuk-bentuk informasi yang sebenarnya diperlukan untuk menunjang keberhasilan operasional perusahaan yang berkaitan dengan kegiatan pengolahan data yang dikehendaki oleh manajemen.

2. Mengatur semua kebutuhan serta membaginya secara sistematis pada beberapa tahap dan bagian, yang nantinya akan dioperasikan secara standar untuk menghemat waktu dan biaya.

3. Menentukan cara pelaksanaan tiap-tiap tugas tersebut.

4. Menentukan tingkat ukuran mutu untuk menilai keberhasilan dan ketidakberhasilan dari tiap-tiap performa tugas-tugas tersebut.

5. Menghilangkan sebanyak mungkin pekerjaan yang akan menghambat implementasi sistem, seperti terjadinya duplikasi (pengulangan yang tidak perlu) mengenai fungsi, tujuan, operasi,

6. Data, formulir-formulir data masukan dan laporan-laporan yang sejenis. Di samping itu, juga mengurangi sebanyak mungkin hal-hal yang tidak bermanfaat, yang mungkin terdapat dalam sistem dan prosedur, aliran data yang tidak efisien, dan laporan-laporan yang kurang bermanfaat atau bahkan tidak berguna.

\section{Pengertian Sistem Informasi}

Menurut James A Hall, 2004, information system is the set of formal procedures by which data are collected processed into information, and distributed to users.

Definisi sistem informasi menurut Ali Masjono Mukhtar, adalah: "Suatu pengorganisasian peralatan untuk mengumpulkan, menginput, memproses, menyimpan, mengatur, mengontrol, dan melaporkan informasi untuk pencapaian tujuan perusahaan."

\section{Pengertian Sistem Informasi Akuntansi}


Menurut James A Hall, 2004, the Accounting Information System comprises 3 major subsystems:

1. The transaction processing systems (TPS), yang mendukung operasi harian dengan banyak dokumen dan pesan untuk pemakai ke seluruh organisasi

2. The general ledger/financial reporting system (GL/FRS), yang memproduksi laporan keuangan yang

3. The management reporting system (MRS), yang menyediakan laporan keuangan untuk tujuan khusus dan informasi yang dibutuhkan dalam pengambilan keputusan untuk manajemen internal.

Menurut Romney \& Steinbart, 2006 hal 67, accounting information system is system that collects, records, stores, and processes data to produce information for decision makers. There are six components of an AIS:

1. Pengguna yang mengoperasikan sistem dan melakukan berbagai macam fungsi

2. Prosedur dan instruksi baik manual dan otomatisasi, terkait di pengumpulan, pemrosesan, dan penyimpanan data tentang aktivitas organisasi

3. Data tentang organisasi dan proses bisnis organisasi

4. Perangkat lunak digunakan untuk memproses data organisasi

5. Infrastuktur dari teknologi informasi, termasuk komputer alat pelengkap, dan alat jaringan komunikasi yang digunakan untuk mengumpulkan, pemrosesan, dan pengiriman data dan informasi

\section{Pengertian Persediaan Barang}

Persediaan barang adalah barang-barang yang dimiliki untuk dijual kembali atau memproduksi barang-barang yang akan dijual. Istilah yang digunakan untuk menunjukkan barang-barang yang dimiliki oleh suatu perusahaan akan tergantung pada jenis usaha perusahaan. Istilah yang dipergunakan dapat dibedakan untuk usaha dagang yaitu perusahaan yang membeli barang dan menjualnya kembali tanpa mengadakan perubahan bentuk barang, dan perusahaan manufaktur yaitu perusahaan yang membeli bahan dan mengubah bentuknya untuk dijual. 
Dalam sistem akuntansi persediaan barang, melibatkan unit organisasi yang terkait, mulai dari masuknya barang sampai pencatatan akuntansi. Unit-unit organisasi dalam sistem akuntansi persediaan barang adalah :

1. Fungsi Gudang, pada bagian gudang diselenggarakan kartu gudang untuk mencatat kuantitas persediaan dan mutasi tiap jenis barang yang di simpan di gudang. Selain itu juga bagian gudang menyelenggarakan kartu barang yng ditempelkan pada penyimpanan barang.

2. Fungsi Akuntansi, pada bagian akuntansi diselenggarakan kartu persediaan yang digunakan untuk mencatat kuantitas dan harga pokok barang yang di simpan di gudang. Di samping itu, kartu persediaan ini merupakan rincian rekening kontrol persediaan yang bersangkutan dalam buku besar. (Mulyadi, $2001 ; 556)$

Perusahaan akan selalu memiliki persediaan. Persediaan secara umum dapat diartikan sebagai hal/benda yang dibeli untuk dijual kembali atau digunakan untuk proses produksi.. Menurut Baridwan (2000:149), persediaan merupakan istilah yang digunakan untuk menunjukkan barang-barang yang dimiliki oleh suatu perusahaan, namun akan tergantung pada jenis usaha perusahaan. Secara umum istilah persediaan barang dipakai untuk menunjukkan barang-barang yang dimiliki perusahaan untuk dijual kembali atau digunakan untuk memproduksi barang-barang yang akan dijual.

\section{Desain Sistem Informasi Akuntansi Persediaan Obat Berbasis Komputer Berdasarkan Batch Number dan Expired Date}

Pengelolaan persediaan obat perlu dilakukan desain sistem yang berbasis komputer. Adapun desain tersebut adalah Formulir Serial Number Transaction Entry. Formulir tersebut disediakan agar bagian gudang dengan mudah dapat melakukan penginputan Serial Number dan tanggal kadaluarsa dari suatu Barang. Penginputan serial number dan tanggal kadaluarsa (expired date) atas barang yang dibeli pada formulir ini dilakukan karena bagian akuntansi tidak memiliki informmasi tentang serial number dan expired date dari barang yang dibeli atau yang akan dijual, dimana informasi tersebut hanya diketahui oleh bagian gudang 
saja.

Namun untuk bagian akuntansi, pada saat melakukan transaksi pembelian tunai dan pembelian kredit seharusnya secara bersamaan diisikan nomer batch dan expired date dari tiap produk yang dibeli. Demikian juga saat transaksi penjualan, harus mengisikan kode produk dengan keyboard memilih daftar produk yang tersedia. Disaat transaksi jual juga perlu ada option untuk memilih apakah akan mencetak bon atau tidak, seandainya tidak tercetak tapi ternyata dibutuhkan oleh client, maka bon bisa dicetak dengan utility re-print, sehingga bon bisa dicetak.

\section{METODOLOGI PENELITIAN}

Sistem kerja komputer pada hakekatnya sinkron dengan proses berlangsungnya system informasi manajemen, yang meliputi kegiatan pengumpulan data (input), pengolahan data (output), penyajian informasi hasil pengolahan (output).

Adapun perancangan sistem semuanya dilakukan melalui metode Data Processing (DP). Adapun data processing tersebut dinamakan Electronic Data Procesing (EDP). Sistem pengolahan data dengan menggunakan komputer yang dinamakan Electronic Data Processing System (EDPS). Data Processing mempunyai pola umum sebagai berikut

Gambar 1

Electronic Data Processing System (EDPS)

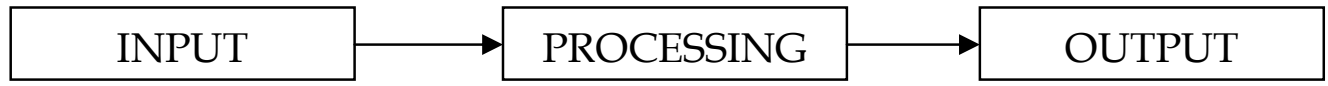

Definisi operasional yang akan diteliti yaitu meliputi konsep, variabel, indikator dan item. Konsep pertama adalah desain sistem atau alur pengoperasian antara lain (a) IPO persediaan obat berdasarkan batch number dan expired date; (b) IPO pembelian kredit obat berdasarkan batch number dan expired date; (c) IPO order pembelian berdasarkan batch number dan expired date; (d) IPO pelunasan hutang berdasarkan batch number dan expired date; (e) IPO penjualan tunai berdasarkan batch number dan expired date pada apotik " $X$ " di Malang; (f) laporan persediaan obat berdasarkan batch number dan expired date pada apotik " $X$ " di Malang? 
Rancangan sistem atau alur pengoperasional desain sistem informasi akuntansi persediaan obat berbasis komputer berdasarkan batch number dan expired date pada halaman berikutnya.

Gambar 2

Desain Sistem Alur Pengoperasional

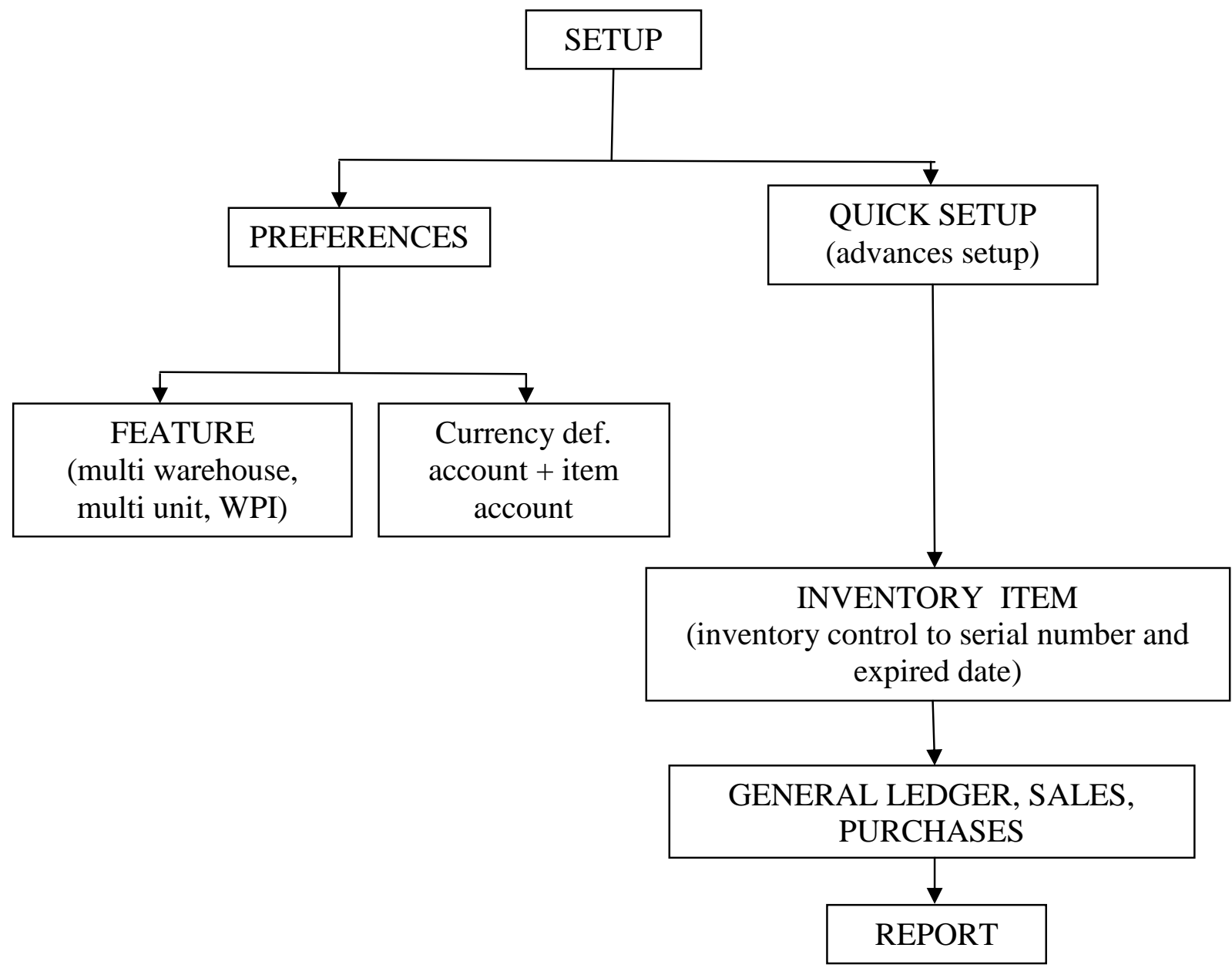

PEMBAHASAN

Desain Sistem Informasi Akuntansi Persediaan Obat dengan Diagram IPO System 
Gambar 3

IPO Persediaan Barang (Inventory) berdasarkan batch number dan expired date

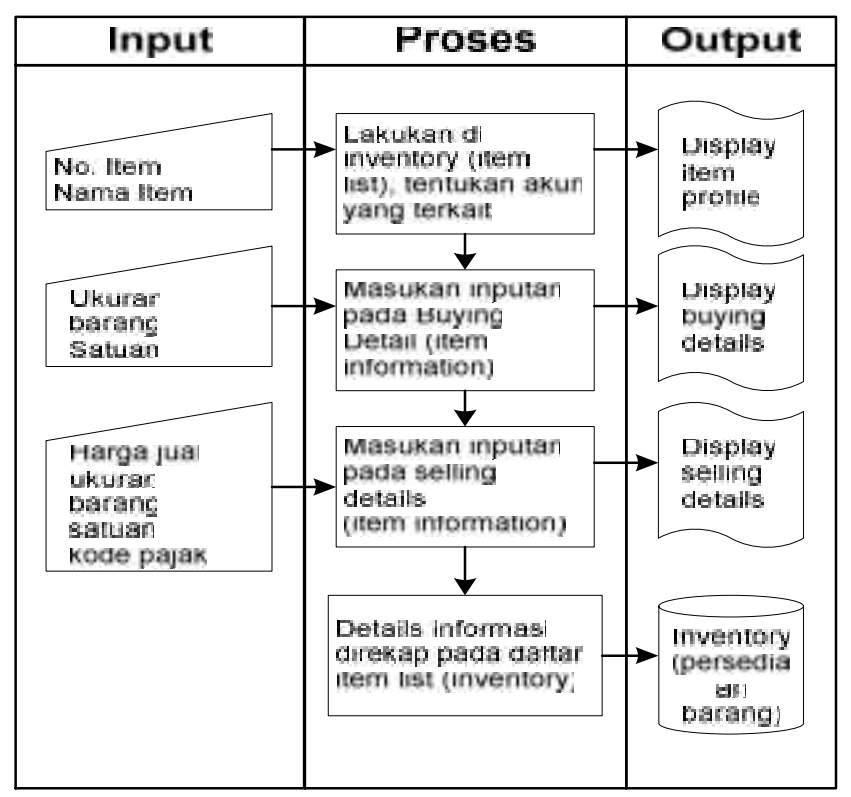

\section{Keterangan:}

Dalam Accurate v.4 pencatatan persediaan barang dikelola dengan menggunakan fasilitas "inventory>item" kemudian entry data barang yaitu inputan berupa kode barang, nama barang, dan inventory control (manage serial number dan expired date) yang dimasukkan dalam jendela items. Selanjutnya tentukan

1. Item category dan warehouse

2. Satuan pembelian item misalnya Buah, Unit, Lusin, Pak dll (multi unit)

3. Tentukan kode pajak pembelian dan penjualan untuk pembelian (dalam hal ini tidak menggunakan pajak / NT)

Setelah inputan dimasukkan dalam pos-pos yang telah disediakan dan diproses dalam jendela item information, seluruh data persediaan barang ini akan disimpan pada item list pada tabel persediaan barang (inventory)

\section{IPO Order Pembelian berdasarkan batch number dan expired date}

Untuk pencatatan transaksi order pembelian sama dengan proses pembelian, tetapi pada transaksi order pembelian ditentukan tanggal pengiriman barang pada kolom expected date, untuk menentukan type pilih purchases order, 
transaksi ini akan dicatat dalam list purchases order sesuai dengan nomor transaksi dan faktur pembelian, tetapi tidak menimbulkan jurnal pembelian maupun jurnal purchases payment, kecuali ada down payment akan berpengaruh pada transaksi pembelian

Gambar 4

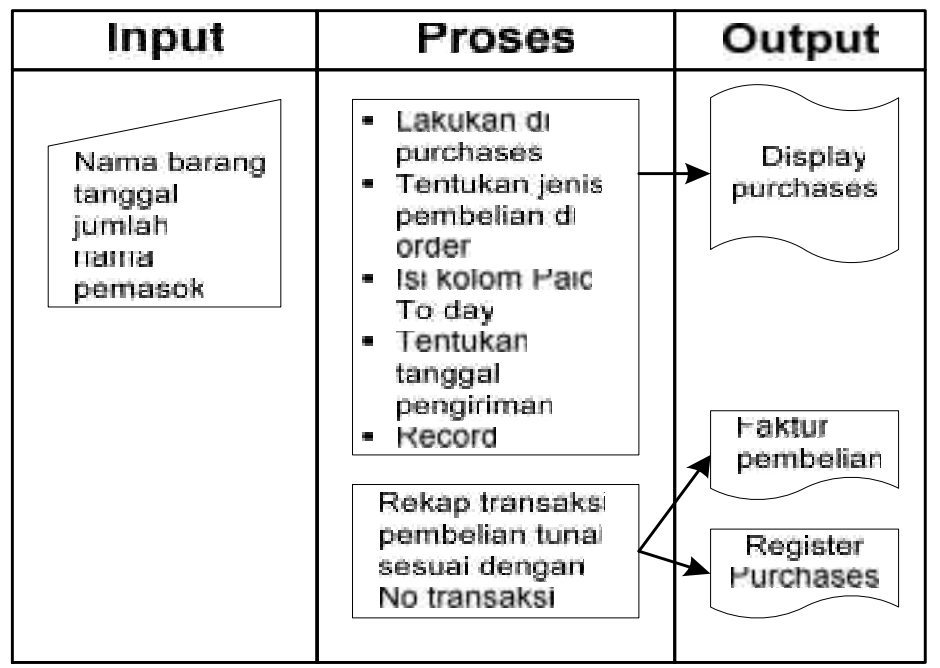

\section{Gambar 5}

IPO Pelunasan Order Pembelian berdasarkan batch number dan expired date

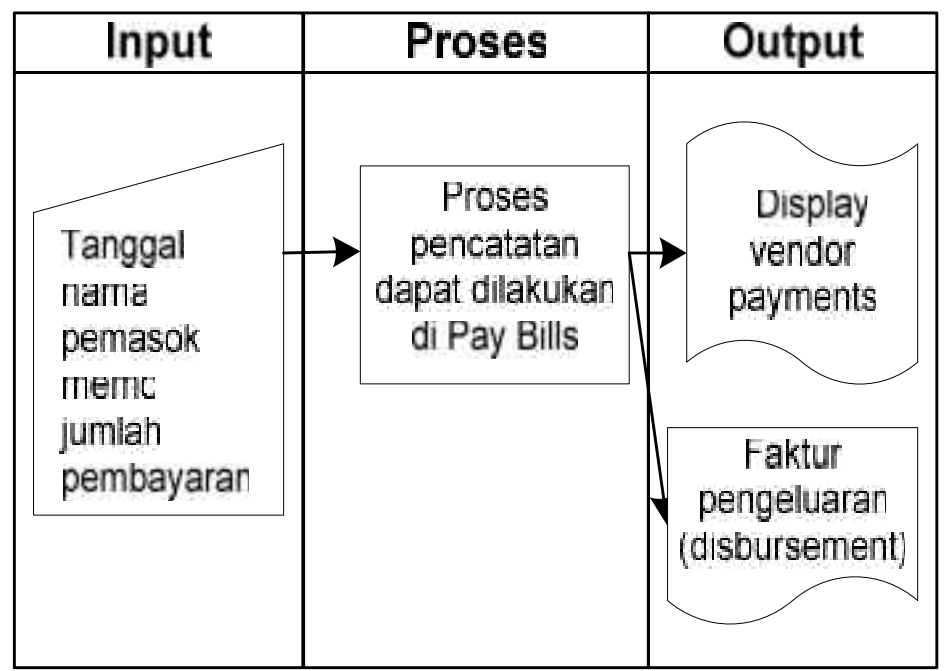

\section{Keterangan:}

Untuk mencatat pelunasan pembayaran atas order pembelian dapat digunakan fasilitas purchases payment. Masukkan tanggal, nama pemasok, memo dan jumlah pembayaran yang harus dilunasi sesuai jumlah yang harus dibayar. Karena 
transaksi ini merupakan pelunasan dari order pembelian maka akan berpengaruh pada jurnal pengeluaran kas.

\section{Gambar 6}

IPO Pembelian Kredit (Uang Muka) berdasarkan batch number dan expired date

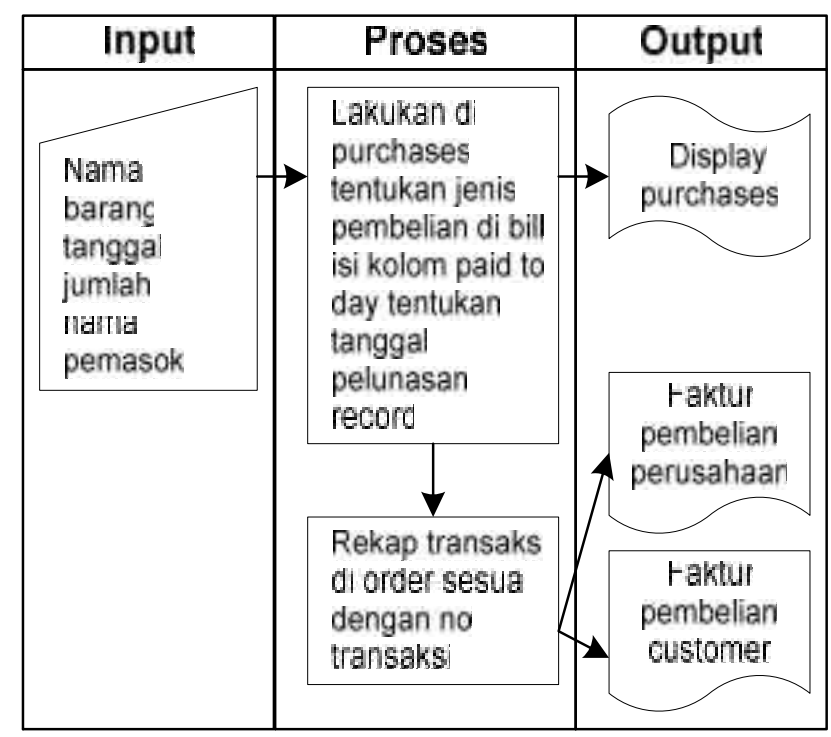

\section{Keterangan :}

Untuk pencatatan transaksi order pembelian sama dengan proses pembelian, tetapi pada transaksi order pembelian ditentukan tanggal pengiriman barang, apabila ada uang muka pilih down payment kemudian diisi jumlah uang muka pada unit price, transaksi ini akan dicatat dalam list purchases sesuai dengan no transaksi dan faktur pembelian transaksi ini akan menimbulkan jurnal pembelian maupun jurnal purchases payment tetapi tidak dengan harga penuh.

\section{Gambar 7}

IPO Pelunasan Hutang berdasarkan batch number dan expired date 


\begin{tabular}{|c|c|c|}
\hline Input & Proses & Output \\
\hline $\begin{array}{l}\text { Nama } \\
\text { pemasok } \\
\text { tangga: } \\
\text { jumian } \\
\text { Ianna } \\
\text { Darang }\end{array}$ & $\begin{array}{l}\text { - Lakukan di } \\
\text { purcnases } \\
\text { - Kuk di ray bius } \\
\text { - isi kolom } \\
\text { Amount \& } \\
\text { Amount Aplied } \\
\text { sesuat jumian } \\
\text { pay buns } \\
\text { - Record }\end{array}$ & $\begin{array}{c}\text { Faktur } \\
\text { pembelıan }\end{array}$ \\
\hline & $\begin{array}{l}\text { Kekap } \\
\text { transaksi d] } \\
\text { purcnases } \\
\text { register }\end{array}$ & $\begin{array}{c}\text { Faktur } \\
\text { pempeiıan } \\
\text { [customer) }\end{array}$ \\
\hline
\end{tabular}

\section{Keterangan:}

Untuk pencatatan transaksi pembelian kredit sama dengan proses pembelian tunai, tetapi transaksi ini mengambil purchases invoice, lalu untuk melunasi hutang klik purchases payment, diisi sesuai dengan jumlah hutang, transaksi ini akan menimbulkan jurnal pembelian maupun jurnal pengeluaran kas

\section{Gambar 8}

IPO Penjualan Tunai (Sales) berdasarkan batch number dan expired date

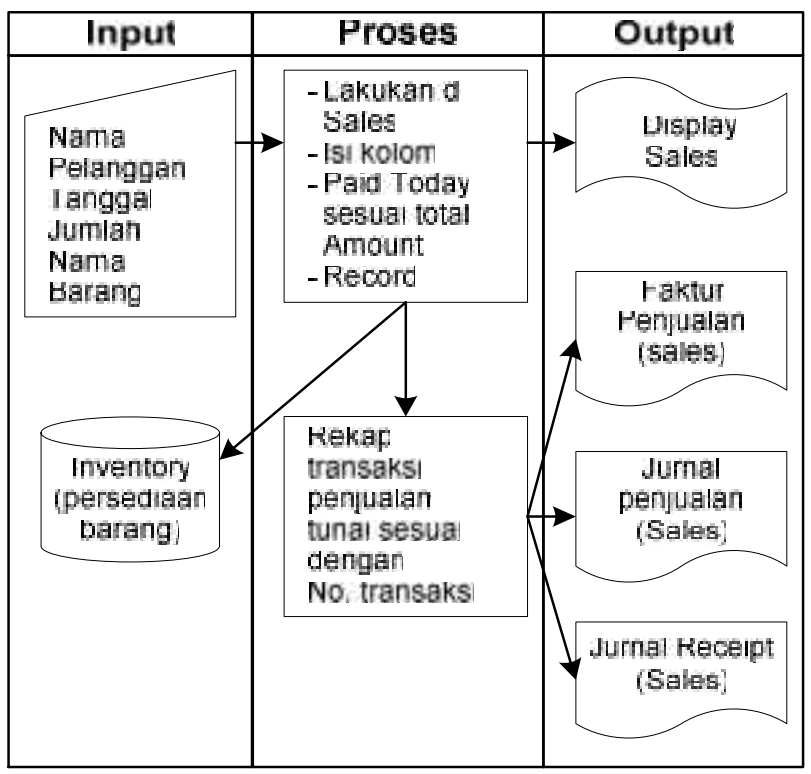

\section{Keterangan :}


Seluruh input berupa nama pemasok, Tanggal, Jumlah barang dan Nama barang. Nama barang diproses di Jendela Sales, untuk penjualan tunai ditentukan jumlah penjualan dengan jumlah di kolom total amount. Transaksi penjualan akan disimpan sesuai dengan jumlah yang dijual di Inventory (Persediaan Barang). Dalam proses ini output (Keluaran) yang dihasilkan dapat berupa Faktur Penjualan (Sales), Jurnal Penjualan Penerimaan Kas (receipts payment).

Gambar 9

Laporan persediaan obat berdasarkan batch number dan expired date

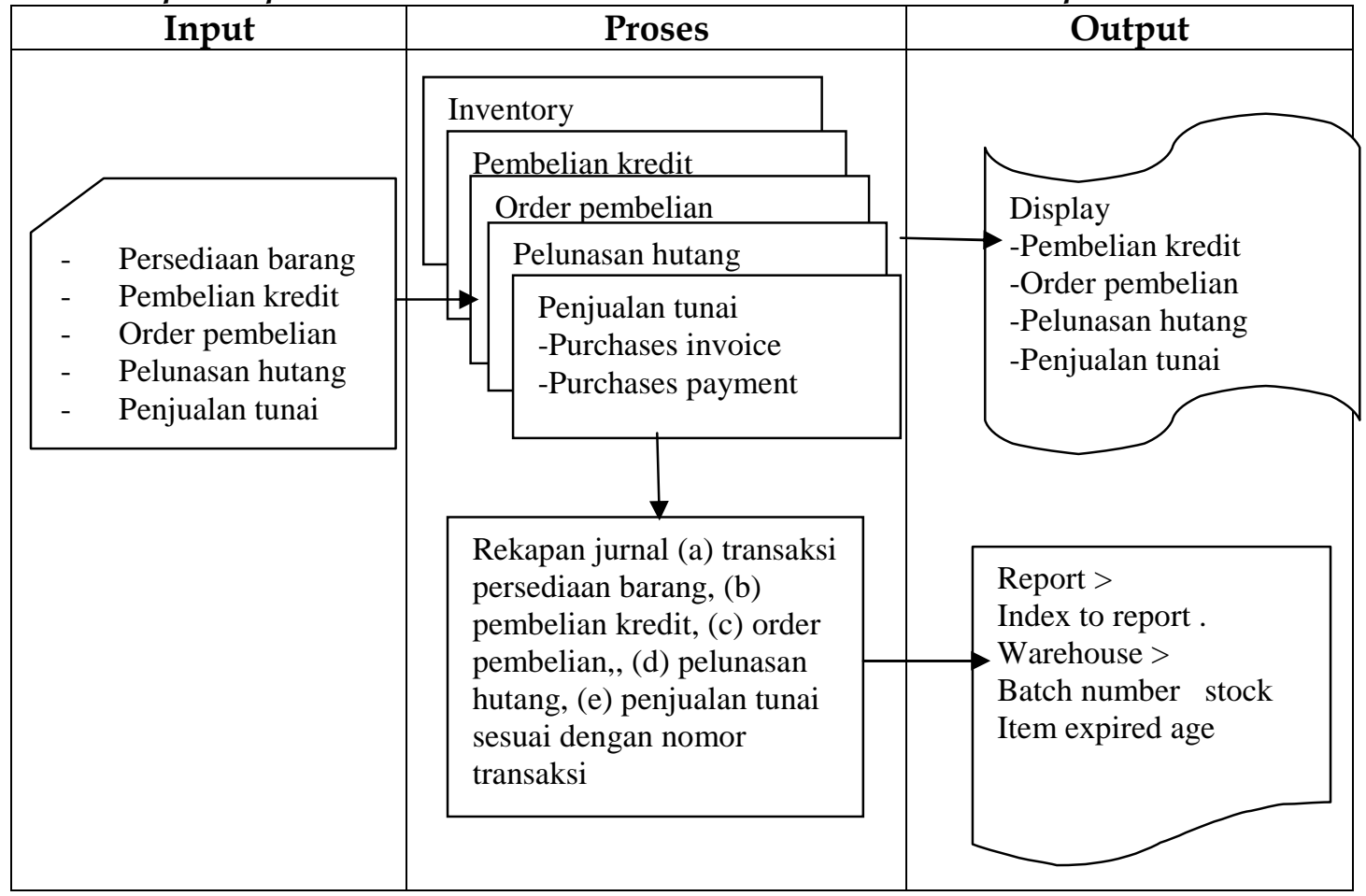

Hasil Desain Aplikasi Sistem Informasi Akuntansi Persediaan Obat Berbasis Komputer berdasarkan Batch Number dan Expired Date

Hasil desain Program Aplikasi dengan menggunakan Accurate v. 4 terdiri dari beberapa transaksi yaitu

\section{Mencatat item Persediaan Pada Inventory}

Tabel barang dan jasa (list of item) berfungsi untuk menampilkan informasi nomor barang (item no), nama barang (description), jumlah barang (quantity), harga jual (unit price), dan informasi tipe barang 
Membuat daftar barang dan jasa dengan cara Klik Inventory $>$ Item $>$ new Item atau bisa juga melalui klik List > Item

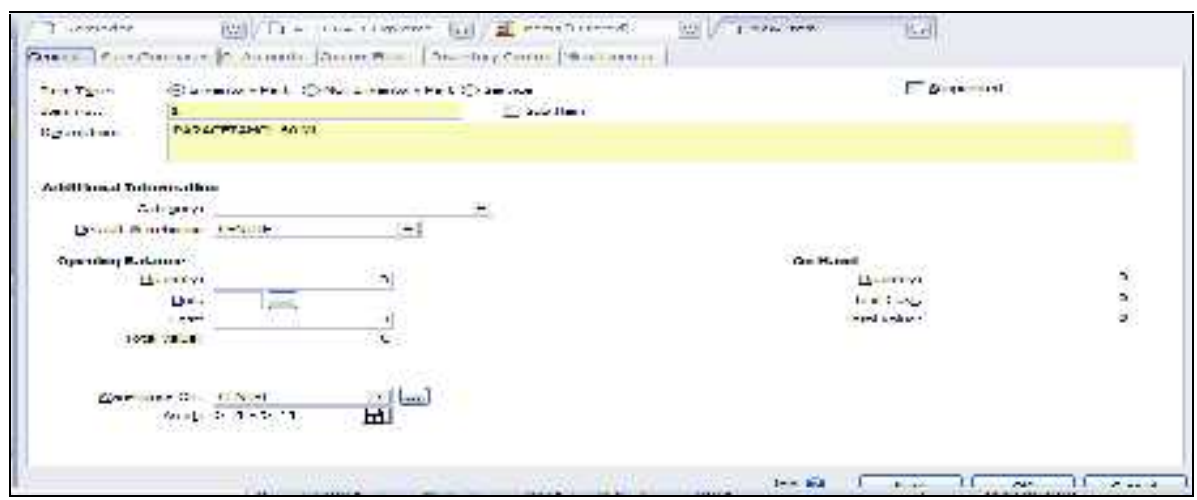

\section{Keterangan}

Item type : pilih tipe barang

Item no : tulis nomor item/barang (maksimal 30 karakter)

Description : ketik nama item (maksimal 240 karakter)

Suspended : dicentang apabila ingin menon-aktifkan item

Sub item : bisa diaktifkan/dipakai apabila item baru yang dibuat merupakan anak item (sub item) dari parent item yang sudah dibuat sebelumnya

Inventory control berguna untuk menentukan apakah item baru yang diinput menggunakan serial number atau tidak. Disamping itu juga menentukan apakah item baru yang diinput mempunyai tanggal kadaluarsa. Berikut tampilan inventory control

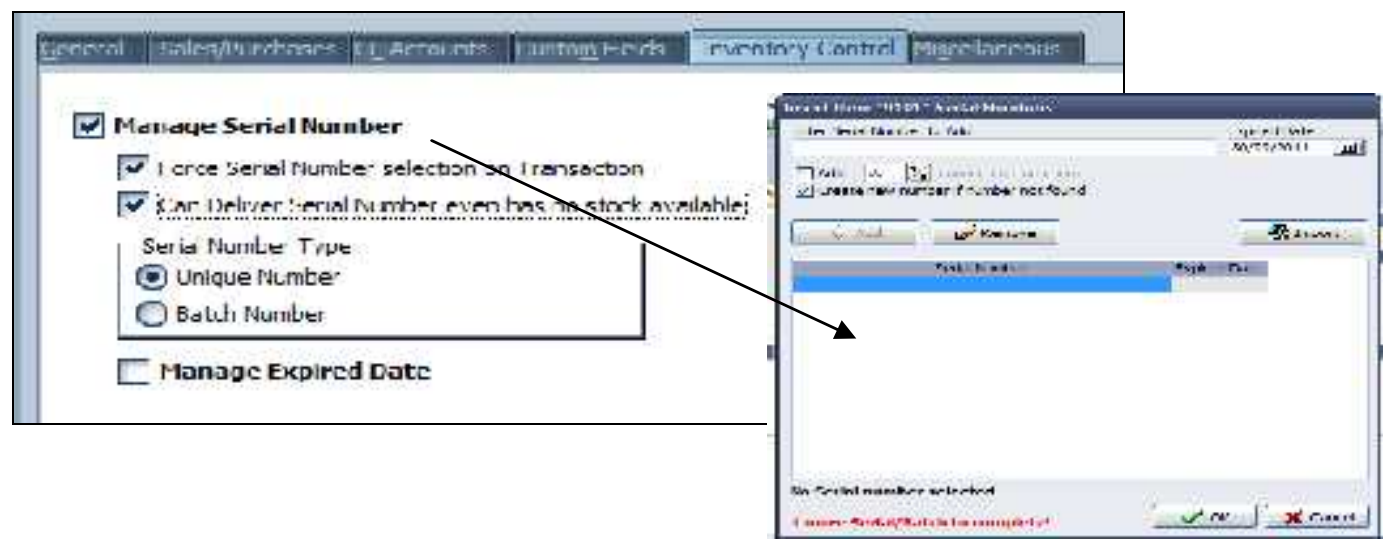




\section{Pembelian kredit (Barang sudah Diterima) Dengan Uang Muka}

Contoh Kasus :

Pada tanggal 4 April 2011 Apotek " $X$ " membeli 50 tab Tremenza (500mg) pada apotik "Y" dengan uang muka 50\% dan sisanya dilunasi pada 10 April 2011

\begin{tabular}{|l|l|l|l|}
\hline No & Nama Item & JML & Harga/ltem \\
\hline 9100 & Tremenza & 50 & Rp.8.000 \\
\hline
\end{tabular}

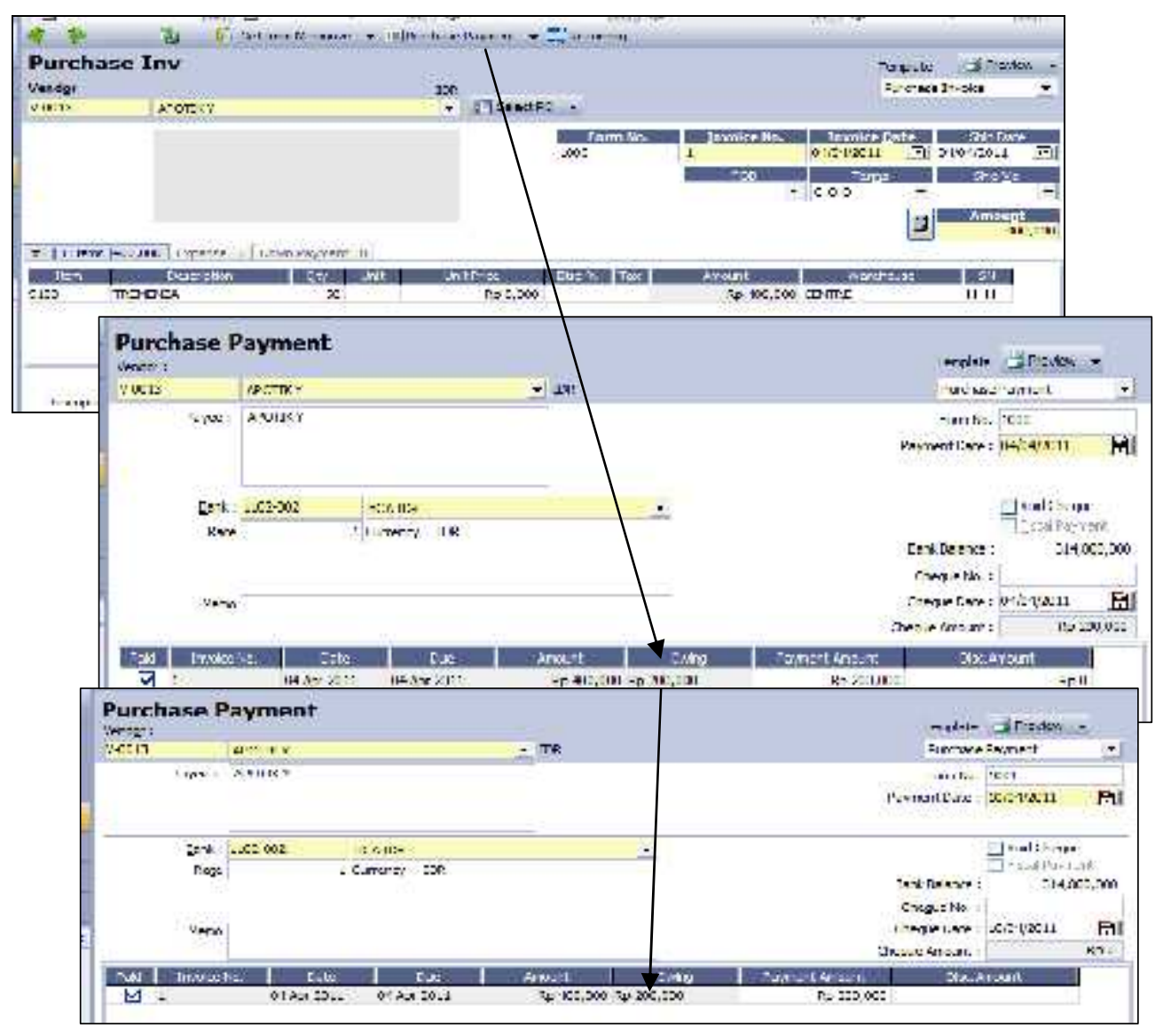

\section{Pencatatan Penjualan Tunai (Pelayanan resep tunai)}

Contoh Kasus :

Pada tanggal 10 April 2008 Apotek " $X$ " menerima resep dari Customer yang bernama Rianti. Adapun resep tersebut untuk 15 bungkus dan diterima pembayaran secara tunai. Isi resep sebagai berikut :

R/ Cefat $300 \mathrm{mg}$

Lasal $\quad 2,5 \mathrm{mg}$

Heptasan 2,5mg

Mycostatine Oral 1/3 tab

\begin{tabular}{|l|l|l|l|}
\hline No Item & Nama Item & JML & Harga/ Item \\
\hline
\end{tabular}




\begin{tabular}{|l|l|l|l|}
\hline 9000 & Resep Rianti & 15 & Rp.21.000 \\
\hline
\end{tabular}

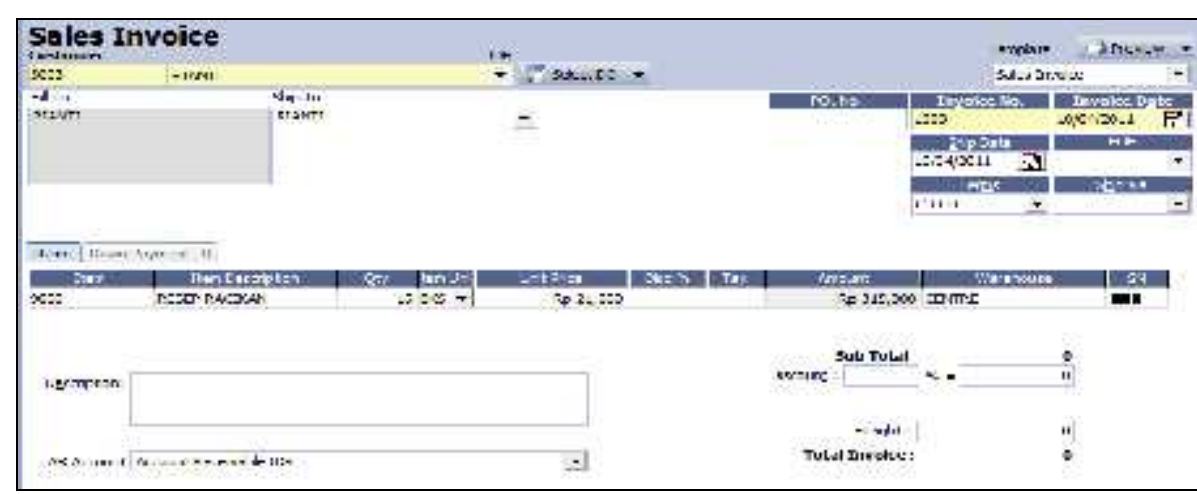

\section{Pencatatan Penjualan Tunai (Pelayanan non resep)}

Contoh Kasus :

Pada tanggal 13 April 2011 Apotek "X" menjual 10 kapsul Lasal (4mg) pada Customer yang bernama Angga secara tunai dan barang langsung diterima Angga

\begin{tabular}{|l|l|l|l|}
\hline No & Nama Item & JML & Harga/ Item \\
\hline 4000 & Lasal $(4 \mathrm{mg})$ & 10 & Rp.1.300 \\
\hline
\end{tabular}

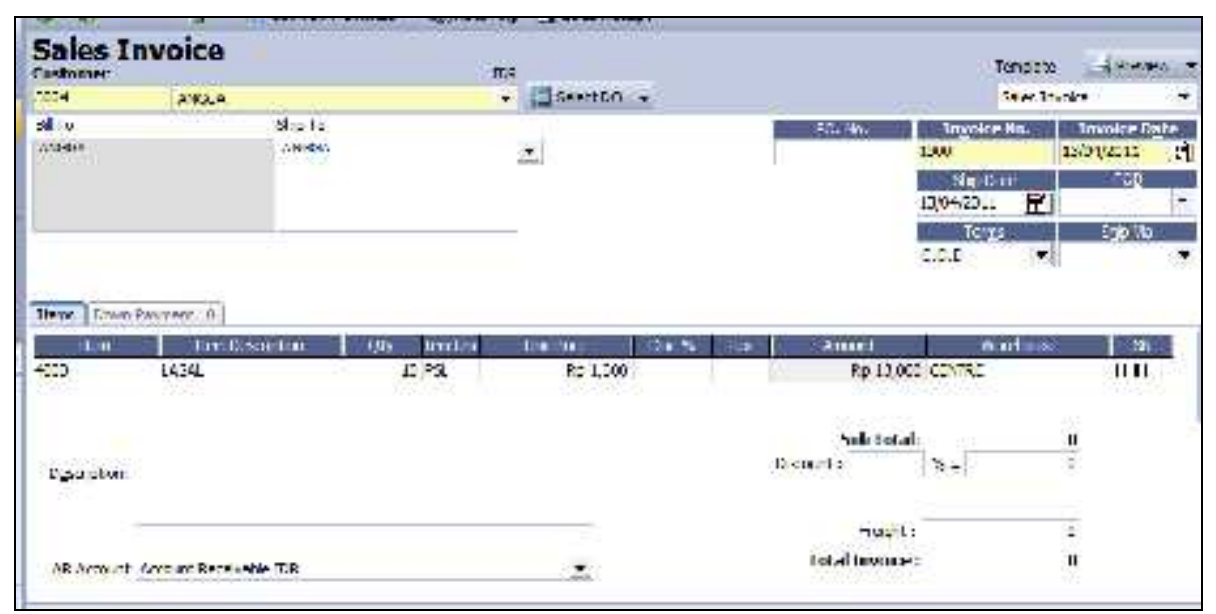

\section{SIMPULAN}

Pengelolaan informasi tentang persediaan obat biasanya dikerjakan secara manual. Tanpa penggunaan sistem informasi akuntansi, maka pendataan persediaan obat melalui proses transaksi jual beli obat yang berdasarkan batch number dan expired date hanya dicatat dalam buku. Kelemahan - kelemahan yang dapat ditemukan dalam kasus ini ialah (a)membutuhkan waktu lebih lama dalam melayani transaksi pembayaran, karena harus dihitung secara manual atau 
dengan kalkulator, (b) memerlukan waktu untuk memantau inventori stok obat yang ada (stock opname) karena dilakukan secara manual, (c) memerlukan waktu dalam pembuatan laporan - laporan, karena karyawan harus membuka kembali data-data yang ada, sehingga pekerjaan menjadi kurang efektif, (d)kemungkinan adanya data - data yang hilang karena tidak/lupa tercatat.

Penggunaan alat bantu komputer sebagai pendukung dalam bidang akuntansi serta perangkat lunak yaitu Accurate v. 4. Adapun dengan menggunakan sistem informasi persediaan obat berbasis komputer maka (a) membutuhkan waktu yang lebih singkat dalam melayani transaksi (c)pembayaran, (b) pemantauan inventori atau stok obat berdasarkan batch number dan expired date yang ada dapat dilakukan lebih cepat, (c) dapat menyajikan laporan persediaan obat berdasarkan batch number dan expired date, (d) pengambilan keputusan yang lebih tepat sasaran, misalnya pemilihan produk atau obat obat mana saja yang lebih diperbanyak karena dengan menggunakan laporan statistik, bisa diketahui produk atau obat mana saja yang paling diminati masyarakat (paling laris).

Berdasarkan simpulan di atas, maka saran yang dapat diberikan kepada apotik " $X "$ di Malang adalah agar mengganti sistem informasi akuntansi persediaan obat berdasarkan batch number dan expired date (melalui proses transaksi pembelian dan transaksi penjualan) yang dimiliki selama ini dengan sistem yang berbasis komputer, yaitu program Accurate v. 4

Program ini diharapkan dapat mengeliminasi kelemahan sistem yang lama sehingga informasi yang dihasilkan bisa lebih informatif, akurat, dan tepat waktu.

Apabila dilihat dari sisi biaya, sumber daya yang dimiliki, baik karyawan maupun peralatan memungkinkan perusahaan untuk menggunakan program Accurate v. 4 hanya perlu ditambahkan kapasitas pada peralatan yang dimiliki dan pelatihan bagi karyawannya.

\section{DAFTAR PUSTAKA}

Basit Agung Wicaksono, 2008. Laporan Hasil PKL Di Apotek Kimia Farma Kediri 
Ikatan Akuntansi Indonesia. (2001). Standar profesional akuntan publik. Jakarta: Salemba Empat Patria.

James A Hall. 2001. Sistem Informasi Akuntansi. Jakarta: Salemba Empat

Kurniawan, Paulus Christianto. 2008. Peranan Sistem Informasi Persediaan Alatalat Medis dalam Menunjang Keefektifan Pengelolaan Persediaan Alat-alat Medis. Laporan Skripsi Universitas Widyatama

Mahmudi, Ali. 2005. Accurate (Sistem Informasi Akuntansi Perusahaan). Penerbit: Gramedia Widiasarana Indonesia. Jakarta

Manual Book Accurate versi 4. 2009. CPSSoft International

Mulyadi, 2001, Sistem Akuntansi, Edisi Ketiga, Penerbit : Salemba Empat. Yogjakarta

Perdiasari, Lutfia. 2009. Advanced Setup Using Accurate 4. Penerbit: Bisnis 2030. Jakarta

Perdiasari, Lutfia. 2009. Mastering Accurate I versi. 4. Penerbit: Bisnis 2030. Jakarta

Perdiasari, Lutfia. SE. 2009. Mastering Accurate versi. 4 Lanjutan. Penerbit: Bisnis 2030. Jakarta

Romney Marshal, Steinbart. 2006. Accounting Information System (Buku Tiga). Jakarta: Salemba Empat

Zaki Baridwan. 2000. Sistem Informasi Akuntansi. Edisi Keenam. Yogyakarta: BPFE 